\section{Nitrogen Availability from Liquid Organic Fertilizers}

\author{
T.K. Hartz ${ }^{1}$, R. Smith ${ }^{2}$, and M. Gaskell ${ }^{2}$
}

\begin{abstract}
ADDITIONAL INDEX WORDS. mineralization, fertigation, drip irrigation
SUMMARY. Limited soil nitrogen $(\mathrm{N})$ availability is a common problem in organic vegetable production that often necessitates additional $\mathrm{N}$ fertilization. The increasing use of drip irrigation has created a demand for liquid organic fertilizers that can be applied with irrigation. The $\mathbf{N}$ availability of three liquid organic fertilizers was evaluated in an incubation study and a greenhouse bioassay. Phytamin 801 contained fishery wastes and seabird guano, while Phytamin 421 and Biolyzer were formulated from plant materials. The fertilizers ranged from 26 to $60 \mathrm{~g} \cdot \mathrm{kg}^{-1} \mathrm{~N}, 8 \%$ to $21 \%$ of which was associated with particulate matter large enough to potentially be removed by drip irrigation system filtration. The fertilizers were incubated aerobically in two organically managed soils at constant moisture at 15 and $25{ }^{\circ} \mathrm{C}$, and sampled for mineral $\mathrm{N}$ concentration after 1,2 , and 4 weeks. In the greenhouse study, these fertilizers and an inorganic fertilizer (ammonium sulfate) were applied to pots of the two organically managed soils with established fescue (Festuca arundinacea) turf; the $\mathrm{N}$ content of clippings was compared with that from unfertilized pots after 2 and 4 weeks of growth. Across soils and incubation temperatures, the $\mathrm{N}$ availability from Phytamin 801 ranged from $79 \%$ to $93 \%$ of the initial $\mathrm{N}$ content after 1 week, and $83 \%$ to $99 \%$ after 4 weeks. The plant-based fertilizers had significantly lower $\mathrm{N}$ availability, but after 4 weeks, had $48 \%$ to $92 \%$ of initial $\mathrm{N}$ in mineral form. Soil and incubation temperature had modest but significant effects on fertilizer $\mathrm{N}$ availability. Nitrification was rapid, with $>90 \%$ of mineral $\mathrm{N}$ in nitrate form after 1 week of incubation at $25^{\circ} \mathrm{C}$, or 2 weeks at $15{ }^{\circ} \mathrm{C}$. $\mathrm{N}$ recovery in fescue clippings 4 weeks after application averaged $60 \%, 38 \%$, and $36 \%$ of initial N content for Phytamin 801, Phytamin 421, and Biolyzer, respectively, equivalent to or better than the $\mathbf{N}$ recovery from ammonium sulfate.
\end{abstract}

$\mathrm{O}$ rganic production has become a significant sector of the vegetable industry in California. Providing sufficient soil nitrogen availability to reach maximum yield potential can be a challenge in organic culture. Cover cropping is generally the most economical way to provide plant-available $\mathrm{N}$ in organic systems (Gaskell and Smith, 2007). In California, cover crop production is typically done over the winter. There are circumstances in which the production of a cover crop is impractical. Water availability or cost to irrigate a cover crop can be an issue. Foregoing cash crop production for the 3 months or more required for cover cropping may be difficult to economically justify on high-value land, particularly when there is a significant seasonal market premium for produce. Unpredictable spring weather can complicate cover crop residue management and delay spring planting. Even where a cover crop is produced, its $\mathrm{N}$ contribution

${ }^{1}$ Department of Plant Sciences, University of California, 1 Shields Drive, Davis, CA 95616-8780

${ }^{2}$ University of California Cooperative Extension, Monterey and Santa Barbara Counties may be inadequate to supply high-N demand crops, and other organic $\mathrm{N}$ sources may be required to maximize crop productivity.

Application of manure-based compost is a common organic production practice, but the low $\mathrm{N}$ mineralization rate typical of compost limits its $\mathrm{N}$ contribution. Hartz et al. (2000) reported that most composts mineralized $<10 \%$ of initial $\mathrm{N}$ content in the 4 to 6 months following soil incorporation. A high compost application rate can make a significant contribution to soil $\mathrm{N}$ availability, but in practice, application rate is constrained by cost and by the potential for water quality degradation from high phosphorus (P) loading (Sharpley et al., 1994).

Dry organic fertilizers such as fishery waste, feather meal, and seabird guano are widely used; these products have high $\mathrm{N}$ content $(>10 \%$ of dry weight) and relatively rapid $\mathrm{N}$ mineralization. When applied to agricultural soils, such products mineralize $60 \%$ to $80 \%$ of $\mathrm{N}$ within 4 to 8 weeks (Hadas and Kautsky, 1994; Hadas and Rosenberg, 1992; Hartz and Johnstone, 2006). A limitation of these dry fertilizers is that they are not easily applied through irrigation systems. Drip irrigation is becoming widely used by organic growers in California, and interest is high in organic fertilizers that can be applied through drip systems. In recent years, a number of liquid organic fertilizers has come to market, but there is little data available on their $\mathrm{N}$ mineralization characteristics or the challenges they pose for application through a drip system. This study was undertaken to document the $\mathrm{N}$ mineralization behavior of a representative group of liquid organic fertilizers and to evaluate their suitability for fertigation in drip systems.

\section{Materials and methods}

The $\mathrm{N}$ availability of three commercial liquid organic fertilizers (Table 1) was evaluated in a laboratory incubation experiment conducted at the University of California-Davis in 2008. These fertilizers were formulated from a variety of feedstocks, including fishery wastes, seabird guano, and plant materials. Ammonium $\left(\mathrm{NH}_{4}-\mathrm{N}\right)$ and nitrate-nitrogen $\left(\mathrm{NO}_{3}-\right.$ $\mathrm{N})$ concentrations were quantified

\begin{tabular}{llll}
\hline $\begin{array}{l}\text { Units } \\
\text { To convert U.S. to SI, } \\
\text { multiply by }\end{array}$ & U.S. unit & SI unit & $\begin{array}{l}\text { To convert SI to U.S., } \\
\text { multiply by }\end{array}$ \\
\hline 100 & $\mathrm{bar}$ & $\mathrm{kPa}$ & 0.01 \\
29.5735 & $\mathrm{fl} \mathrm{oz}$ & $\mathrm{mL}$ & 0.0338 \\
3.7854 & gal & $\mathrm{L}$ & 0.2642 \\
2.54 & inch $(\mathrm{es})$ & $\mathrm{cm}$ & 0.3937 \\
25.4 & inch $(\mathrm{es})$ & $\mathrm{mm}$ & 0.0394 \\
0.4536 & $\mathrm{lb}$ & $\mathrm{kg}$ & 2.2046 \\
1.1209 & $\mathrm{lb} / \mathrm{acre}$ & $\mathrm{kg} \cdot \mathrm{ha}^{-1}$ & 0.8922 \\
1 & micron & $\mu \mathrm{m}$ & 1 \\
28.3495 & $\mathrm{oz}$ & $\mathrm{g}$ & 0.0353 \\
0.001 & $\mathrm{ppm}$ & $\mathrm{g} \cdot \mathrm{kg}^{-1}$ & 1000 \\
0.001 & $\mathrm{ppm}$ & $\mathrm{g} \cdot \mathrm{L}^{-1}$ & 1000 \\
1 & $\mathrm{ppm}$ & $\mathrm{mg} \cdot \mathrm{kg}^{-1}$ & 1 \\
$\left({ }^{\circ} \mathrm{F}-32\right) \div 1.8$ & ${ }^{\circ} \mathrm{F}$ & ${ }^{\circ} \mathrm{C}$ & $\left(1.8 \times{ }^{\circ} \mathrm{C}\right)+32$ \\
& & &
\end{tabular}


Table 1. Initial macronutrient composition and form of the liquid organic fertilizers.

\begin{tabular}{lccc}
\hline Parameter $^{\mathrm{z}}$ & Phytamin $\mathbf{8 0 1}$ & Phytamin $^{\mathrm{y}} \mathbf{1}^{\mathrm{y}}$ & Biolyzer $^{\mathrm{y}}$ \\
\hline Feedstock & $\begin{array}{c}\text { Fish waste, } \\
\text { seabird guano }\end{array}$ & $\begin{array}{c}\text { Soy meal, } \\
\text { plant extracts }\end{array}$ & $\begin{array}{c}\text { Grain } \\
\text { fermentation }\end{array}$ \\
Nitrogen $\left(\mathrm{g} \cdot \mathrm{kg}^{-1}\right)$ & 60.2 & 39.6 & 25.9 \\
Total & 4.9 & 7.3 & 5.5 \\
Particulate & 12.5 & 4.7 & 1.7 \\
Ammonium-nitrogen $\left(\mathrm{NH}_{4}-\mathrm{N}\right)$ & 0.4 & 7.3 & 1.8 \\
Nitrate-nitrogen $\left(\mathrm{NO}_{3}-\mathrm{N}\right)$ & 1.6 & 3.4 & 6.0 \\
Carbon:nitrogen $(\mathrm{ratio})$ & 5.7 & 7.2 & 12.4 \\
Total phosphorus $\left(\mathrm{g} \cdot \mathrm{kg}^{-1}\right)$ & 8.5 & 13.6 & 18.7 \\
Total potassium $\left(\mathrm{g} \cdot \mathrm{kg}^{-1}\right)$ & & &
\end{tabular}

${ }^{\mathrm{z}} 1 \mathrm{~g} \cdot \mathrm{kg}^{-1}=1000 \mathrm{ppm}$.

yhytamin 801 and Phytamin 421 manufactured by California Organic Fertilizers, Hanford, CA; Biolyzer manufactured by Converted Organics of California, Gonzales, CA

${ }^{x}$ Nitrogen content of particles retained on No. 4 filter paper.

using a flow injection analyzer (Lachat Instruments, Milwaukee). Total $\mathrm{N}$ was determined by a combustion technique using a Formacs analyzer (Skalar, Norcross, GA). Total P and potassium $(\mathrm{K})$ concentrations were determined by atomic absorption spectrometry and inductively coupled plasma atomic emission spectrometry (ICP-AES), respectively, following nitric acid/hydrogen peroxide microwave digestion (Sah and Miller, 1992).

To estimate the potential loss of $\mathrm{N}$ during filtration in the application of these liquid fertilizers through drip irrigation systems, triplicate samples of each fertilizer were analyzed for total $\mathrm{N}$ concentration before and after passing through filter paper (grade 4; Whatman, Florham Park, NJ). The particle retention of this paper (particulates $>20-25 \mu \mathrm{m}$ retained) was similar to that of a high-quality sand media irrigation system filter.

Soils were collected from the surface $20 \mathrm{~cm}$ of two fields under organic management (no pesticides or synthetic fertilizers applied for $>3$ years), air-dried, and screened through a 5-mm sieve. Soil 1 was a Yolo sandy clay loam (mixed, nonacid, thermic Typic Xerorthents) with 6.6 and $0.7 \mathrm{~g} \cdot \mathrm{kg}^{-1}$ carbon $(\mathrm{C})$ and $\mathrm{N}$, respectively. Soil 2 was an Elder sandy loam (coarse-loamy, mixed, thermic Pachic Haploxeroll) with 8.2 and 0.8 $\mathrm{g} \cdot \mathrm{kg}^{-1} \mathrm{C}$ and $\mathrm{N}$, respectively.

Centrifuge tubes $(50 \mathrm{~mL}$ volume) were filled with $15 \mathrm{~g}$ of dry soil, which was then wetted to a moisture content equivalent to $25 \mathrm{kPa}$ soil moisture tension. The solution used to wet the soil contained sufficient unfiltered fertilizer to enrich the dry soil by $100 \mathrm{mg} \cdot \mathrm{kg}^{-1} \mathrm{~N}$. Four tubes of each soil wetted with tap water, and four tubes of each soil $\times$ fertilizer combination, were immediately extracted with $2 \mathrm{~N}$ potassium chloride $(\mathrm{KCl})$ for determination of initial $\mathrm{NH}_{4}-\mathrm{N}$ and $\mathrm{NO}_{3}-\mathrm{N}$ concentration. The remaining tubes were sealed in 1-L volume glass jars and incubated at a constant temperature of 15 or $25^{\circ} \mathrm{C}$. This temperature range encompassed the seasonal fluctuation of soil temperature typical of the coastal valleys of central California where the use of these liquid fertilizers is most common. After 1, 2, and 4 weeks, three replicate tubes of each unfertilized soil and each soil $\times$ fertilizer combination were extracted with $2 \mathrm{~N} \mathrm{KCl}$ for mineral $\mathrm{N}$ determination. The increase in mineral $\mathrm{N}$ concentration over time (compared with the change in unfertilized soil) represented net $\mathrm{N}$ availability from the organic fertilizers.

Plant $\mathrm{N}$ uptake from the organic fertilizers was evaluated in a greenhouse bioassay. On 23 July 2008, sod of tall fescue was planted in 1-L pots filled with the organically managed field soils used in the incubation experiment. Fescue was chosen as the test organism because prior research (Hartz et al., 2000) showed it to be suitable for this purpose. The sod was allowed to grow in the pots for 5 weeks in a greenhouse, after which the fescue was clipped and a single application of fertilizer was made at a rate equivalent to $30 \mathrm{lb} /$ acre $\mathrm{N}$ on a surface area basis. A plug of sod was removed in the center of each pot; the fertilizer was applied to the underlying soil and then covered with sand and lightly irrigated. All fertilizers were applied as a $6 \mathrm{~g} \cdot \mathrm{L}^{-1} \mathrm{~N}$ solution. Pots receiving no fertilization were included in the experiment, as were pots receiving an equivalent rate of a mineral fertilizer [ammonium sulfate, $\left.\left(\mathrm{NH}_{2}\right)_{2} \mathrm{SO}_{4}\right]$.

The pots were arranged in a randomized complete block design. Within each of three blocks, there were two pots representing each soil/ fertilizer combination; clippings from those two pots were combined for dry weight measurement and $\mathrm{N}$ analysis. The greenhouse was maintained at a $25 / 20{ }^{\circ} \mathrm{C}$ day/night regime. Pots were irrigated daily, with leachate captured and reapplied. The fescue was clipped 2 and 4 weeks after fertilizer application. The clippings were oven-dried, weighed, ground, and analyzed for total $\mathrm{N}$ concentration by combustion (analyzer model FP528; LECO, St. Joseph, MI). N recovery from the applied fertilizers was estimated by comparing the $\mathrm{N}$ content of fescue clippings from fertilized pots with those from pots receiving no fertilizer.

Data were analyzed using the SAS General Linear Model procedure (version 9.1; SAS Institute, Cary, NC). Differences among fertilizer treatments were further evaluated using Duncan's multiple range test.

\section{Results and discussion}

The organic fertilizers had total $\mathrm{N}$ concentrations ranging from 25.9 to $60.2 \mathrm{~g} \cdot \mathrm{kg}^{-1}$ (Table $\mathrm{l}$ ), closely matching the product label analysis $\left(60,40\right.$, and $25 \mathrm{~g} \cdot \mathrm{kg}^{-1} \mathrm{~N}$ for Phytamin 801, Phytamin 421, and Biolyzer, respectively). Initial mineral $\mathrm{N}$ ranged from $14 \%$ to $30 \%$ of total $\mathrm{N}$ content, predominately as $\mathrm{NH}_{4}-\mathrm{N}$ in the animal-based Phytamin 801, and $\mathrm{NO}_{3}-\mathrm{N}$ in the plant-based fertilizers (Phytamin 421 and Biolyzer). From $8 \%$ to $21 \%$ of total $\mathrm{N}$ content was associated with particulate matter large enough to be at risk of removal by a drip irrigation filtration system. $\mathrm{C}: \mathrm{N}$ ratio varied from 1.6 to 6.0 . Total $\mathrm{P}$ and $\mathrm{K}$ ranged from 5.7 to 12.4 and 8.5 to $18.7 \mathrm{~g} \cdot \mathrm{kg}^{-1}$, respectively.

Net $\mathrm{N}$ mineralization over the incubation period was generally similar between the two unamended soils (Fig. 1). An average of $0.7 \%$ or $1.6 \%$ of initial soil organic $\mathrm{N}$ content was 


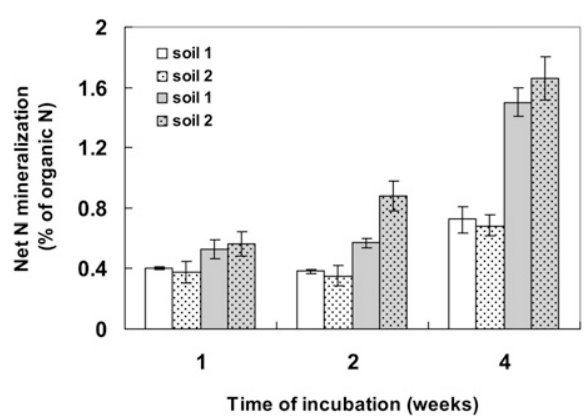

Fig. 1. Effect of incubation temperature and time of incubation on net nitrogen $(\mathrm{N})$ mineralization of the unfertilized soils used in the incubation experiment; bars indicate SE of measurement. Unshaded bars represent incubation at $15^{\circ} \mathrm{C}$, shaded bars at $25{ }^{\circ} \mathrm{C} ;\left(1.8 \times{ }^{\circ} \mathrm{C}\right)+32={ }^{\circ} \mathrm{F}$.

mineralized over 4 weeks at 15 or 25 ${ }^{\circ} \mathrm{C}$, respectively. This was in the range of mineralization estimates from other California soils in long-term vegetable rotations (Hartz et al., 2000; Krueskopf et al., 2002). These results documented that conditions conducive to mineralization were maintained throughout the experiment.

Interactions among soil, temperature, and fertilizer treatment required fertilizer performance to be evaluated separately for each soil and temperature combination (Table 2). Phytamin 801 and Phytamin 421 had $>60 \%$ of initial $\mathrm{N}$ content in mineral form after 1 week of incubation, and more than $70 \%$ after 2 weeks. Biolyzer, the fertilizer with the lowest $\mathrm{N}$ content and highest $\mathrm{C}: \mathrm{N}$ ratio, had significantly lower $\mathrm{N}$ availability; after 4 weeks $\mathrm{N}$ availability ranged from only $48 \%$ to $66 \%$ of initial N content. Nitrification occurred rapidly; across fertilizers and soils, more than $90 \%$ of mineral $\mathrm{N}$ was in $\mathrm{NO}_{3}-\mathrm{N}$ form after 1 week of incubation at $25^{\circ} \mathrm{C}$, or after 2 weeks at $15^{\circ} \mathrm{C}$. There were small but statistically significant $(P<0.05)$ soil and temperature effects on fertilizer $\mathrm{N}$ availability, with greater $\mathrm{N}$ availability found in soil 2 , and at $25^{\circ} \mathrm{C}$.

The fescue assay confirmed the rapid $\mathrm{N}$ availability of Phytamin 801, with apparent fertilizer $\mathrm{N}$ recovery (ANR) in fescue clippings 4 weeks after application averaging $60 \%$ across soils (Table 3). Phytamin 421 and Biolyzer averaged $38 \%$ and $36 \%$ ANR, respectively, statistically equivalent to that from ammonium sulfate. ANR was significantly higher in soil 2 than soil 1 , averaging $39 \%$ and $50 \%$ of applied $\mathrm{N}$ after 4 weeks of growth, respectively. It should be noted that since only the clippings of fescue were analyzed rather than the entire plant biomass, the reported $\mathrm{N}$ recovery may have underestimated actual plant uptake of fertilizer N. Higher N recovery with Phytamin 801 than with ammonium sulfate may have reflected less $\mathrm{N}$ loss through denitrification. In pot culture, some degree of soil saturation is inevitable, and denitrification is likely; the prolonged $\mathrm{N}$ mineralization from organic fertilizers would limit mineral $\mathrm{N}$ concentrations at any given time, and therefore potentially limit denitrification. Also, because the organic fertilizers contained other nutrients, they may have had a stimulatory effect on fescue growth unrelated to $\mathrm{N}$ availability.

The $\mathrm{N}$ availability characteristics of the fertilizer comprised of animal wastes (Phytamin 801) was somewhat higher than those of dry organic fertilizers from comparable feedstocks (Hartz and Johnstone, 2006). In that study, fish powder and seabird guano mineralized more than $50 \%$ of organic $\mathrm{N}$ content within 2 weeks at $15^{\circ} \mathrm{C}$ or higher, with mineralization slowing thereafter. The authors hypothesized that the rapid initial mineralization observed was due to enzymatic hydrolysis of simple compounds such as urea and amino acids. Although this process is temperature dependent (Loll and Bollag, 1983; Moyo et al., 1989), these highly labile forms of organic $\mathrm{N}$ were exhausted relatively quickly even at $15{ }^{\circ} \mathrm{C}$. Additional mineralization required the slower process of microbial degradation of more complex organic $\mathrm{N}$ forms.

In the current study, $\mathrm{N}$ availability of Phytamin 801 was enhanced by the higher initial mineral $\mathrm{N}$ content (21\% of initial $\mathrm{N}$ compared with $<7 \%$ for the dry fertilizers evaluated by Hartz and Johnstone, 2006), suggesting that some hydrolysis may have occurred during product formulation. The slower $\mathrm{N}$ availability of the plant-based fertilizers suggested that more complex $\mathrm{N}$ forms predominated in those products. Another factor that may have contributed to rapid $\mathrm{N}$

Table 2. Nitrogen $(\mathrm{N})$ availability from organic fertilizers as influenced by temperature and time of incubation.

\begin{tabular}{|c|c|c|c|c|c|c|c|c|c|}
\hline \multirow{3}{*}{$\begin{array}{l}\text { Weeks of } \\
\text { incubation }\end{array}$} & \multirow[b]{3}{*}{ Fertilizer $^{\mathrm{z}}$} & \multicolumn{4}{|c|}{ Mineral $\mathrm{N}$ availability at $15^{\circ} \mathrm{C}(\%)^{\mathrm{y}}$} & \multicolumn{4}{|c|}{ Mineral $\mathrm{N}$ availability at $25^{\circ} \mathrm{C}(\%)^{\mathrm{y}}$} \\
\hline & & \multicolumn{2}{|c|}{ Soil 1 } & \multicolumn{2}{|c|}{ Soil 2} & \multicolumn{2}{|c|}{ Soil 1} & \multicolumn{2}{|c|}{ Soil 2} \\
\hline & & Total & as $\mathrm{NO}_{3}-\mathrm{N}$ & Total & as $\mathrm{NO}_{3}-\mathrm{N}$ & Total & as $\mathrm{NO}_{3}-\mathrm{N}$ & Total & as $\mathrm{NO}_{3}-\mathrm{N}$ \\
\hline 1 & Phytamin 421 & $62 \mathrm{~b}$ & 71 & $65 \mathrm{~b}$ & 76 & $71 \mathrm{~b}$ & 99 & $75 \mathrm{~b}$ & 99 \\
\hline & Biolyzer & $35 \mathrm{c}$ & 66 & $36 \mathrm{c}$ & 70 & $42 \mathrm{c}$ & 99 & $50 \mathrm{c}$ & 99 \\
\hline & Mean & 59 & & 62 & & 65 & & 73 & \\
\hline & Biolyzer & $40 \mathrm{c}$ & 99 & $45 \mathrm{c}$ & 99 & $45 \mathrm{c}$ & 99 & $55 \mathrm{c}$ & 99 \\
\hline \multirow{4}{*}{4} & Mean & 65 & & 68 & & 67 & & 77 & \\
\hline & Phytamin 801 & $83 a$ & 99 & $93 \mathrm{a}$ & 99 & $84 \mathrm{a}$ & 99 & $99 \mathrm{a}$ & 99 \\
\hline & Phytamin 421 & $74 \mathrm{~b}$ & 99 & $79 \mathrm{~b}$ & 99 & $71 \mathrm{~b}$ & 99 & $92 \mathrm{~b}$ & 99 \\
\hline & Biolyzer & $48 \mathrm{c}$ & 99 & $50 \mathrm{c}$ & 99 & $50 \mathrm{c}$ & 99 & $66 c$ & 99 \\
\hline
\end{tabular}

"Phytamin 801 and Phytamin 421 manufactured by California Organic Fertilizers, Hanford, CA; Biolyzer manufactured by Converted Organics of California, Gonzales, CA. y Percentage of initial fertilizer $\mathrm{N}$ now in mineral form $\left[\right.$ ammonium-nitrogen $\left(\mathrm{NH}_{4}-\mathrm{N}\right)+$ nitrate-nitrogen $\left.\left(\mathrm{NO}_{3}-\mathrm{N}\right)\right] ;\left(1.8 \times{ }^{\circ} \mathrm{C}\right)+32={ }^{\circ} \mathrm{F}$.

${ }^{x}$ Means within columns within incubation times separated using Duncan's multiple range test at $P<0.05$. 
Table 3. Apparent recovery of fertilizer nitrogen $(\mathrm{N})$ in fescue clippings 2 and 4 weeks after fertilizer application in the greenhouse trial.

\begin{tabular}{lcc}
\hline & \multicolumn{2}{c}{ Recovery of fertilizer $\mathbf{N}$ (\% of applied $\mathbf{N})$} \\
\cline { 2 - 3 } Fertilizer $^{\mathrm{z}}$ & $\mathbf{2}$ weeks & 4 weeks \\
\hline Phytamin 801 & $39 \mathrm{a}^{\mathrm{y}}$ & $60 \mathrm{a}$ \\
Phytamin 421 & $22 \mathrm{~b}$ & $38 \mathrm{~b}$ \\
Biolyzer & $20 \mathrm{~b}$ & $36 \mathrm{~b}$ \\
Ammonium sulfate & $25 \mathrm{~b}$ & $39 \mathrm{~b}$ \\
Soil & & \\
1 & 24 & 39 \\
2 & 30 & 50 \\
& $*$ & $*$ \\
\hline
\end{tabular}

${ }^{2}$ Phytamin 801 and Phytamin 421 manufactured by California Organic Fertilizers, Hanford, CA; Biolyzer manufactured by Converted Organics of California, Gonzales, CA.

${ }^{y}$ Means within columns separated using Duncan's multiple range test at $P<0.05$.

${ }^{*}$ Soil response significantly different at $P<0.05$.

availability in the liquid fertilizers was the fine particle size required to make a colloidal suspension; the greater reactive surface area of fine particles may speed microbial degradation.

As the fescue assay demonstrated, these liquid organic fertilizers can function similarly to conventional $\mathrm{N}$ fertilizers. Their rapid $\mathrm{N}$ availability is radically different from that of other sources of $\mathrm{N}$ in organic culture. Less than half of the $\mathrm{N}$ contained in a cover crop may become plant-available in the growing season after incorporation (Gaskell and Smith, 2007). N contribution from manure-based compost is even slower, often limited to $<10 \%$ of $\mathrm{N}$ content (Hartz et al., 2000). The rapid $\mathrm{N}$ availability, and rapid nitrification, of these liquid organic fertilizers undercuts the rationale for use of Chilean nitrate (mined $\mathrm{NaNO}_{3}$ ), which proponents prize as a source of readily available $\mathrm{NO}_{3}-\mathrm{N}$ in cool soil conditions. For growers who oppose the use of $\mathrm{NaNO}_{3}$ on philosophical grounds, or who ship organic products to countries in which its use is prohibited, liquid organic fertilizers provide a viable alternative.

Clearly, liquid organic fertilizers can be a useful tool, particularly in the production of high- $\mathrm{N}$ demand crops, or long-season crops such as strawberry (Fragaria $\times$ ananassa) in which significant $\mathrm{N}$ demand occurs many months after original field preparation. However, the use of such fertilizers may be constrained by cost, and by maintenance issues if applied in a drip irrigation system. The products tested ranged from about $\$ 13$ to $\$ 18$ per kilogram $\mathrm{N}$. While these products contain some $\mathrm{P}$ and $\mathrm{K}$, other organically approved sources of those nutrients are readily available at lower cost. Growers who inject liquid organic fertilizers without proper filtration run the risk of clogging drip emitters; depending on the type of filtration used, frequent backflushing may be required to maintain system flow. The loss of particulate $\mathrm{N}$ with filtration further increases the cost of the $\mathrm{N}$ applied.

Where in-season $\mathrm{N}$ application is required to meet crop $\mathrm{N}$ demand, we conclude that liquid organic fertilizers can be effective, even under cool soil conditions. Given the high cost and potential complication of irrigation system maintenance, the use of these products should be minimized, and other sources of $\mathrm{N}$ (cover cropping and/or compost application) should form the basis of an organic $\mathrm{N}$ fertility plan.

\section{Literature cited}

Gaskell, M. and R. Smith. 2007. Nitrogen sources for organic vegetable production. HortTechnology 17:431-441.

Hadas, A. and L. Kautsky. 1994. Feather meal, a semi-slow release nitrogen fertilizer for organic farming. Fert. Res. 38: 165-170.

Hadas, A. and R. Rosenberg. 1992. Guano as a nitrogen source for fertigation in organic farming. Fert. Res. 31:209214.

Hartz, T.K. and P.R. Johnstone. 2006. Nitrogen availability from high-nitrogencontaining organic fertilizers. HortTechnology 16:39-42.

Hartz, T.K., J.P. Mitchell, and C. Giannini. 2000. Nitrogen and carbon mineralization dynamics of manures and composts. HortScience 35:209-212.

Krueskopf, H.H., J.P. Mitchell, T.K. Hartz, D.M. May, E.M. Miyao, and M.D. Cahn. 2002. Pre-sidedress soil nitrate testing identifies processing tomato fields not requiring sidedress $\mathrm{N}$ fertilizer. HortScience 37:520-524.

Loll, M.J. and J. Bollag. 1983. Protein transformations in soil. Adv. Agron. 36: 351-382.

Moyo, C.C., D.E. Kissel, and M.L. Cabrera. 1989. Temperature effects on soil urease activity. Soil Biol. Biochem. 21:935-938.

Sah, R.N. and R.O. Miller. 1992. Spontaneous reaction for acid dissolution of biological tissues in closed vessels. Anal. Chem. 64:230-233.

Sharpley, A.N., S.C. Chapra, R. Wedepohl, J.T. Sims, T.C. Daniels, and K.R. Reddy. 1994. Managing agricultural phosphorus for the protection of surface waters: Issues and options. J. Environ. Qual. 23:437451 . 